\title{
Hypoxia-induced mitogenic factor (HIMF/FIZZ1/RELMa) in chronic hypoxia- and antigen-mediated pulmonary vascular remodeling
}

Daniel J Angelini ${ }^{1}$, Qingning Su', Kazuyo Yamaji-Kegan ${ }^{1}$, Chunling Fan ${ }^{1}$, John T Skinner ${ }^{1}$, Andre Poloczek', Hazim El-Haddad ${ }^{2}$, Chris Cheadle ${ }^{3}$ and Roger A Johns ${ }^{1,4^{*}}$

\begin{abstract}
Background: Both chronic hypoxia and allergic inflammation induce vascular remodeling in the lung, but only chronic hypoxia appears to cause $\mathrm{PH}$. We investigate the nature of the vascular remodeling and the expression and role of hypoxia-induced mitogenic factor (HIMF/FIZZ1/RELMa) in explaining this differential response.

Methods: We induced pulmonary vascular remodeling through either chronic hypoxia or antigen sensitization and challenge. Mice were evaluated for markers of $\mathrm{PH}$ and pulmonary vascular remodeling throughout the lung vascular bed as well as HIMF expression and genomic analysis of whole lung.

Results: Chronic hypoxia increased both mean pulmonary artery pressure (mPAP) and right ventricular (RV) hypertrophy; these changes were associated with increased muscularization and thickening of small pulmonary vessels throughout the lung vascular bed. Allergic inflammation, by contrast, had minimal effect on mPAP and produced no RV hypertrophy. Only peribronchial vessels were significantly thickened, and vessels within the lung periphery did not become muscularized. Genomic analysis revealed that HIMF was the most consistently upregulated gene in the lungs following both chronic hypoxia and antigen challenge. HIMF was upregulated in the airway epithelial and inflammatory cells in both models, but only chronic hypoxia induced HIMF upregulation in vascular tissue.

Conclusions: The results show that pulmonary vascular remodeling in mice induced by chronic hypoxia or antigen challenge is associated with marked increases in HIMF expression. The lack of HIMF expression in the vasculature of the lung and no vascular remodeling in the peripheral resistance vessels of the lung is likely to account for the failure to develop PH in the allergic inflammation model.
\end{abstract}

Keywords: Pulmonary hypertension, Hypoxia-induced mitogenic factor (HIMF), Chronic hypoxia, Th2-mediated inflammation, Vascular remodeling

\footnotetext{
* Correspondence: rajohns@jhmi.edu

${ }^{1}$ Department of Anesthesiology and Critical Care Medicine, Johns Hopkins University School of Medicine, 720 Rutland Avenue, Ross 361, Baltimore, MD 21205, USA

${ }^{4}$ Division of Pulmonary and Critical Care Medicine, Department of Medicine, Johns Hopkins University School of Medicine, Baltimore, MD 21205, USA

Full list of author information is available at the end of the article
} 


\section{Background}

Pulmonary hypertension $(\mathrm{PH})$ is clinically defined by a mean pulmonary artery pressure $(\mathrm{mPAP}) \geq 25 \mathrm{mmHg}$ at rest $[1,2]$. This condition can manifest itself as a primary disease (idiopathic with or without a genetic linkage) or as a complication of another disease such as collagen vascular disease (e.g., scleroderma), human immunodeficiency virus (HIV) infection, Shistosoma mansoni (S. mansoni) infection, or chronic obstructive pulmonary disease [1-4]. The exact initiating event in the pathogenesis of $\mathrm{PH}$ is largely unknown, but several conditions, including chronic hypoxia and chronic pulmonary inflammation, have been associated with the development of $\mathrm{PH}$ in humans [5-7]. These conditions induce endothelial cell dysfunction as well as endothelial and vascular smooth muscle cell proliferation and hypertrophy within the pulmonary circulation [8]; changes in the cells of the vasculature thicken pulmonary arteries and arterioles, narrowing their lumens, resulting in increases in pulmonary vascular pressure and resistance $[5,8,9]$.

A growing body of evidence suggests that inflammation plays a role in the vascular remodeling associated with chronic hypoxia and other experimental manifestations of PH [10-14]; these findings have accelerated investigation into the potential mechanisms of inflammation in this disease process [7]. Burke et al. [11] reported the upregulation of several pro-inflammatory genes in the lungs, including stromal cell-derived factor1 (SDF-1/CXCL12), monocyte chemoattractant protein1 (MCP-1), and interleukin (IL)-6, as well as the accumulation of monocytes within the pulmonary vasculature during chronic hypoxia. Also, many studies have shown that T-cell helper 2 (Th2) cytokines, particularly IL-4 and IL-13, are involved in the pathogenesis of pulmonary vascular remodeling [13-18]. We have recently reported that IL-4 acts as a proangiogenic molecule in the lungs of mice during chronic hypoxia [13]. To examine the role of Th2 cytokines in pulmonary vascular remodeling, Daley et al. [15] modified the standard antigen-challenge model normally used to examine inflammatory asthma. In this modified model, extended antigen challenges with either ovalbumin (Ova) or Aspergillus fumigatus antigen (Asp ag) lacking any viable fungus produced severe pulmonary vascular remodeling involving the proliferation of vascular smooth muscle cells. This remodeling was reduced in both IL-4 knockout mice and mice that had IL-13 signaling neutralized [15]. Surprisingly, this model produced no increases in right ventricular systolic pressure. In an S. mansoni infection model of PH, Graham et al. [19] demonstrated that mice that lacked the IL-13 decoy receptor, IL-13R $\alpha 2$, displayed more severe pulmonary vascular remodeling than did wild-type controls. They also reported an increase in right ventricle (RV) maximum pressure in the infected IL13R $\alpha 2$ knockout mouse compared to uninfected wild-type controls. In a separate study, Swain et al. [17] reported pulmonary vascular remodeling and development of $\mathrm{PH}$ as a result of Pneumocystis pneumonia in both wild-type and $\mathrm{CD}_{4}^{+}$ T-cell-depleted mice; notably, these pathological changes still occurred in IL-4 knockout mice, and IL-13 was not detected in the lungs of the mice during the persistent phase of the model [17]. These studies suggest a role for inflammation in pulmonary vascular remodeling, but currently, the exact involvement in this process is unclear.

Hypoxia-induced mitogenic factor (HIMF), also known as "found in inflammatory zone 1" (FIZZ1) or "resistinlike molecule alpha" (RELM $\alpha)$, is highly upregulated in the lung in response to both chronic hypoxia $[10,20,21]$ and Th2-mediated inflammation [16,17,22-27]. We have demonstrated that HIMF has proliferative, angiogenic, vasoconstrictive, and chemokine-like properties that are associated with the development of $\mathrm{PH}[10,20,21,28,29]$. We have also demonstrated that overexpression of HIMF within the lungs induces a pattern of vascular remodeling and hemodynamic changes similar to that in chronic hypoxia-induced $\mathrm{PH}$ and that the in vivo blockade of HIMF expression within the lung reduces the pathologic vascular and hemodynamic changes associated with this model $[10,20]$. These data indicate that HIMF plays a direct role in the induction of pulmonary vascular remodeling and the development of $\mathrm{PH}$ associated with chronic hypoxia. HIMF is also upregulated in response to pulmonary inflammation $[16,17$, 22-25,27,30]. It has been reported that HIMF expression is increased in the lungs of several models of Th2-dependent inflammation, including allergic asthma [15,22,23,27], human herpes virus 8 infection [25], Pneumocystis pneumonia [17], S. mansoni infection $[16,19]$, and bleomycin-induced pulmonary fibrosis $[24,30]$; all of these models are associated with pulmonary vascular remodeling. Our laboratory has demonstrated that a tail vein injection of recombinant murine HIMF into mice induces a pro-inflammatory state within the lungs associated with vascular remodeling [14] and that HIMF can induce de novo production of both SDF-1 and MCP-1 in cultured endothelial cells and ex vivo lung organ culture [14,29]. We have also shown that the human isoform of HIMF, RELM $\beta$, is upregulated in the lungs of patients diagnosed with scleroderma-associated $\mathrm{PH}$ [31]. In lung samples from these patients, RELM $\beta$ was expressed in inflammatory cells (macrophages, T-cells) as well as in myofibroblasts, endothelium, and vascular smooth muscle [31]. Renigunta et al. [32] also demonstrated that hypoxia could induce human RELM $\beta$ expression in both a lung 
cancer cell line (A549) and primary pulmonary artery smooth muscle cells in vitro.

At the current time, it remains unclear whether Th2 models of vascular remodeling induction, including Ova, Asp ag, and S. mansoni infection, actually cause the development of $\mathrm{PH}$ as chronic hypoxia does (e.g. increased mPAP, RV hypertrophy, vascular remodeling). In the current study, we directly compare chronic hypoxiaand Th2 inflammation-induced pulmonary vascular remodeling to address this issue and identify possible explanations of the observed differences.

\section{Methods}

\section{Experimental animals}

Adult male C57BL/6 mice (6-8 weeks old; Charles River Laboratories, Wilmington, MA) were used for all of the studies. The animal housing and experimental protocols were approved by the Animal Care and Use Committee of the Johns Hopkins University. The mice had free access to food and water and were housed in a room with a $12: 12$ h light-dark cycle at $20-24^{\circ} \mathrm{C}$.

\section{Ova model of Th2-induced pulmonary vascular remodeling}

The Ova used for this study was prepared as follows: Ova (Grade V; Sigma-Aldrich, St. Louis, MO) was diluted to $1 \mathrm{mg} / \mathrm{ml}$ in $0.15 \mathrm{M}$ sterile saline that was complexed with Alum (Imject Alum; Thermo Fisher Scientific, Waltham, MA). Mice were injected i.p. with $50 \mu \mathrm{g}$ Ova and $2 \mathrm{mg}$ Alum or equivalent volume of sterile saline solution on day 0 of the experiment. This procedure was then repeated on day 14 . On days 28-30, the mice were intranasally challenged with $50 \mu \mathrm{g}$ Ova diluted in $50 \mu \mathrm{l}$ of saline or with $50 \mu \mathrm{l}$ saline alone. The intranasal challenges were also repeated on days 35-37, 41-43, and 45. Mice were sacrificed on day 46 of the experiment by isoflurane overdose, and tissue was processed as we have described [10,20]. Mice used for hemodynamic measurement were anesthetized with an i.p. injection of ketamine $(100 \mathrm{mg} / \mathrm{kg})$ and xylazine (10 $\mathrm{mg} / \mathrm{kg}$ ), and mPAP was determined as described $[20,21]$. All mice were euthanized by exsanguination. Bronchoalveolar lavage fluid (BALF) was collected by injecting the airways with $0.8 \mathrm{ml}$ of sterile saline solution under constant pressure via a 22-gauge catheter inserted into the trachea followed by removal under constant pressure. The BALF was centrifuged to remove cells and cell particles; the supernatant was stored at $-80^{\circ} \mathrm{C}$ for use in Western blotting. The heart and lungs from each mouse were removed en bloc. The right lung was tied off, and the left lung was inflated with $1 \%$ low-melt agarose in PBS with constant pressure $\left(25 \mathrm{~cm} \mathrm{H}_{2} \mathrm{O}\right)$ and placed on ice as we have described previously [10,20]. The right lung was removed and frozen in liquid nitrogen and stored at $-80^{\circ} \mathrm{C}$ for use in Western blotting. The heart was then removed and the agarose-inflated left lung was placed in $10 \%$ neutral buffered formalin (Thermo Fisher Scientific) at $4^{\circ} \mathrm{C}$ for $48-72 \mathrm{~h}$. Following fixation, the left lung was processed for paraffin embedding. The heart was then dissected into the RV and left ventricle plus septum $(\mathrm{LV}+\mathrm{S})$. Both portions of the heart were then weighed and the $R V$ and $L V+S$ ratio determined $[\mathrm{RV} /(\mathrm{LV}+\mathrm{S})]$.

\section{Asp ag model of Th2-induced pulmonary vascular remodeling}

Asp ag that did not contain any viable fungus (GREER Laboratories, Inc., Lenoir, $\mathrm{NC}$ ) was diluted to $1 \mathrm{mg} / \mathrm{ml}$ in sterile saline. Mice were injected i.p. with $100 \mu \mathrm{l}$ of this solution on days 0 and 14 of this experiment. On days 28-30, the mice were intranasally challenged with $100 \mu \mathrm{g}$ Asp ag diluted in $50 \mu \mathrm{l}$ of saline or with $50 \mu \mathrm{l} \mathrm{sa-}$ line alone. The intranasal challenges were also repeated on days $35-37,41-43$, and 45 . On day 46 , the mice were sacrificed and processed as stated above.

\section{Chronic hypoxia model of pulmonary vascular remodeling}

Mice were exposed to normal room air $\left(20.8 \% \mathrm{O}_{2}\right)$ or $10.0 \% \mathrm{O}_{2}$ for 4 or 28 days as we have described [10,20,21,33-36]. The mice were housed in Plexiglas hypoxia chambers that had continuous air flow. The fractional concentration of $\mathrm{O}_{2}$ was monitored and controlled with a Pro:Ox model 350 unit (Biospherix, Redfield, NY) by infusion of $\mathrm{N}_{2}$ (Roberts Oxygen; Rockville, MD) balanced against an inward leak of air through holes in the chamber. $\mathrm{CO}_{2}$ and ammonia were scavenged throughout the experiment. At each time point, the mice were sacrificed and processed as stated above.

\section{Assessment of pulmonary vascular remodeling}

Pulmonary vascular remodeling was assessed in a blinded fashion as we have previously described [10,20,33-36]. For our initial evaluation, lung sections were stained with hematoxylin and eosin. To evaluate the muscularization of pulmonary vessels, we dual stained additional lung sections for von Willebrand Factor (endothelium) and $\alpha$-smooth muscle actin (vascular smooth muscle) as we have previously described [10,20,35,36]. We then examined approximately 100 randomly selected peripheral vessels ( $<80 \mu \mathrm{m}$ in diameter) from each mouse ( $\mathrm{n} \geq 3$ for each experimental group) under an Olympus-BHS microscope attached to a QImaging Retiga 4000RV digital camera. These vessels were classified as non-muscular (NM), partially muscular (PM), or fully muscular (FM) and analyzed as we have published [10,20]. Vascular remodeling was also evaluated by the percent of medial 
thickness (\%MT) of pulmonary vessels as described $[20,33]$. Briefly, \%MT was determined on the murine lung sections receiving Movat pentachrome stain and calculated as follows: \%MT $=[($ external diameter internal diameter)/external diameter $] \times 100$. For these studies, we evaluated vessels that had an external diameter between 25 and $150 \mu \mathrm{m}$. Approximately 30 vessels in 30 consecutive fields were evaluated per lung. Pulmonary vessels were classified as either peribronchial or intra-alveolar. MetaMorph software (Molecular Devices, Downingtown, PA) was used to make the measurements.

\section{Western blot analysis}

Frozen mouse lung tissue was homogenized on ice with a Brinkman Homogenizer (Polytron, Westbury, NY) in homogenization/lysis buffer and the resultant protein assayed as we have described [20]. The lung and BALF samples were resolved by a 4-20\% SDS-PAGE (Bio-Rad, Hercules, CA) gel and transferred onto nitrocellulose (Bio-Rad) membranes. The membranes were blocked with $5 \%$ milk in Tris-buffered saline with $0.1 \%$ Tween 20 (TBS-T) for $1 \mathrm{~h}$ and then incubated with polyclonal goat anti-mouse RELM $\alpha$ (1:500; R\&D Systems, Minneapolis, $\mathrm{MN}$ ) antibodies in $5 \% \mathrm{milk} / \mathrm{TBS}-\mathrm{T}$ overnight at $4^{\circ} \mathrm{C}$. The blots were then incubated in rabbit anti-goat IgG antibodies (1:5000; Bio-Rad) conjugated to horseradish peroxidase in $5 \%$ milk/TBS-T for $1 \mathrm{~h}$ at room temperature. Enhanced chemiluminescence (Amersham, Piscataway, NJ) was used to develop the blots followed by exposure to X-ray film (Denville Scientific, Metuchen, NJ). To ensure equal loading and transfer, blots were stripped with Blot Restore Membrane Rejuvenation Kit (Millipore) and reprobed with murine anti- $\beta$ actin (Santa Cruz Biotechnology, Santa Cruz, CA).

\section{Immunohistochemistry}

Paraffin blocks of murine lungs exposed to saline challenge, Ova challenge, normoxia $\left(20.8 \% \mathrm{O}_{2}\right)$, or hypoxia $\left(10.0 \% \mathrm{O}_{2}\right)$ were cut into $6-\mu \mathrm{m}$ sections and placed on clean positively charged glass slides. We deparaffinized, rehydrated, and performed antigen retrieval on the slides as described [10,20]. Endogenous peroxidases, avidin, and biotin were blocked as described $[10,20]$. Nonspecific protein binding was blocked by incubating the sections in normal rabbit serum for $1 \mathrm{~h}$ at room temperature. Then, the sections were treated with polyclonal goat anti-mouse RELM $\alpha$ (1:200; R\&D Systems, Minneapolis, $\mathrm{MN}$ ) antibodies or antibody diluent alone overnight at $4^{\circ} \mathrm{C}$. After being washed with PBS, the slides were treated with rabbit anti-goat biotinylated secondary antibodies and then an $\mathrm{ABC}$ horseradish peroxidase reagent (Vectastain Elite $A B C$ Kit; Vector Laboratories) for $30 \mathrm{~min}$ each at room temperature. The HIMF signal was developed with the Peroxidase Substrate Kit DAB (Vector Laboratories), counterstained with hematoxylin, dehydrated, and mounted as we have described $[10,20]$. The signal was visualized with an Olympus-BHS microscope attached to a QImaging Retiga 4000RV digital camera. Images were captured with ImagePro Plus (version 5.1) software.

\section{Immunofluorescence microscopy}

Paraffin-embedded murine lung tissue was sectioned, deparaffinized, and rehydrated; antigen retrieval was performed as described under Immunochemistry. The slides were then washed with PBS, and nonspecific protein binding was blocked by incubating the sections in normal horse serum for $1 \mathrm{~h}$ at room temperature. The sections were then treated with polyclonal rabbit anti-mouse RELM $\alpha$ (1:200; Abcam, Cambridge, MA) and mouse anti- $\alpha$-smooth muscle actin (1:500), rat antiF4/80 (1:100; Serotec, Raleigh, NC), mouse anti-CD3 (1:200; Santa Cruz Biotechnology), rat anti-major basic protein (MBP; 1:500; Santa Cruz Biotechnology), rat anti-neutrophil (NIMP-R14; 1:100; Abcam), rat antiCD19 (1:200; Abcam), or diluents alone overnight at $4^{\circ} \mathrm{C}$. Next, the sections were incubated with DyLight 488labeled goat anti-rabbit IgG $(\mathrm{H}+\mathrm{L})$ (1:200; Jackson ImmunoResearch Labs, Inc., West Grove, PA) and either DyLight 594-labeled donkey anti-mouse IgG $(\mathrm{H}+\mathrm{L})$ (1:200; Jackson ImmunoResearch Labs, Inc.) or DyLight 594-labeled donkey anti-rat IgG $(\mathrm{H}+\mathrm{L})$ (1:200; Jackson ImmunoResearch Labs, Inc.) for $45 \mathrm{~min}$ at room temperature in the dark. Finally, the sections were washed in PBS, mounted with Vectashield Hardset Mounting Media with 4,6'-diamidino-2-phenylindole dilactate (DAPI; Vector Laboratories), covered with a glass coverslip, and visualized with an Olympus-BHS microscope attached to a QImaging Retiga 4000RV digital camera. Images were captured by using ImagePro Plus (version 5.1) software and colorized with Adobe Photoshop CS5 software (Adobe Systems, Inc., San Jose, CA).

\section{Genomic analysis}

RNA was extracted from lung tissue with the Trizol Reagent method (Invitrogen, Carlsbad, CA). Additional purification was performed on RNAeasy columns (Qiagen, Valencia, CA). The quality of total RNA samples was assessed by using an Agilent 2100 Bioanalyzer (Agilent Technologies, Palo Alto, CA). The RNA samples were labeled according to the chip manufacturer's recommended protocols. Briefly, $0.5 \mu \mathrm{g}$ of total RNA from each sample was labeled by using the Illumina TotalPrep RNA Amplification Kit (Ambion, Austin, TX) in a two-step process of cDNA synthesis followed by in vitro RNA transcription. Single stranded RNA (cRNA) 
was generated and labeled by incorporating biotin-16UTP (Roche Diagnostics GmbH, Mannheim, Germany). Seven hundred fifty nanograms of biotin-labeled cRNA was hybridized for $16 \mathrm{~h}$ to Illumina Sentrix Mouse Ref8_v1.1 BeadChips (Illumina, San Diego, CA). The hybridized biotinylated cRNA was detected with streptavidin-Cy3 and quantified by using Illumina's BeadStation 500GX Genetic Analysis Systems scanner. Preliminary analysis of the scanned data was performed with Illumina BeadStudio software, which returns single intensity data values/gene following the computation of a trimmed mean average for each probe type represented by a variable number of bead probes/gene on the array. Z-transformation for normalization was performed on each Illumina sample/array on a stand-alone basis [37], and significant changes in gene expression between class pairs were calculated by Z test [38]. Significant gene lists were calculated by selecting genes that satisfied a significance threshold criteria of $\mathrm{Z}$ test $P$ values $\leq 0.001$, a false discovery rate $\leq 0.1$ [39], and a fold change \pm 1.5 or greater. Changes in gene expression across multiple groups were tested for by one-way ANOVA. Gene expression signatures robustly identified on the basis of statistical significance were tested against multiple sample datasets by using a systematic gene set analytical approach such as Parametric Analysis of Gene Expression (PAGE) [40] or Gene Set Enrichment
Analysis [41]. Differential regulation of related gene expression signatures were quantified and compared by using Gene Set Matrix Analysis [42], a modification of the PAGE method in which multiple gene lists were automatically tested against one or more datasets for parametric enrichment (using the log ratios of calculated changes in gene expression for the entire dataset).

\section{Statistical analysis}

Experimental values are expressed as means \pm standard error of the mean (SEM). A paired Student's $t$-test was used to compare the mean responses between two groups. ANOVA was used to compare the mean responses between experimental and control groups for experiments containing multiple groups. The Tukey multiple comparison test was used to determine between which groups significant differences existed. A $P$ value of $<0.05$ was considered statistically significant.

\section{Results}

Induction of pulmonary vascular remodeling by chronic hypoxia and Th2 inflammation

Mice exposed to chronic hypoxia exhibited increased muscularization and thickening of the pulmonary vasculature as well as mild inflammation, when compared to normoxic controls (Figure 1A). The Ova-challenged mice displayed vascular remodeling mainly around the
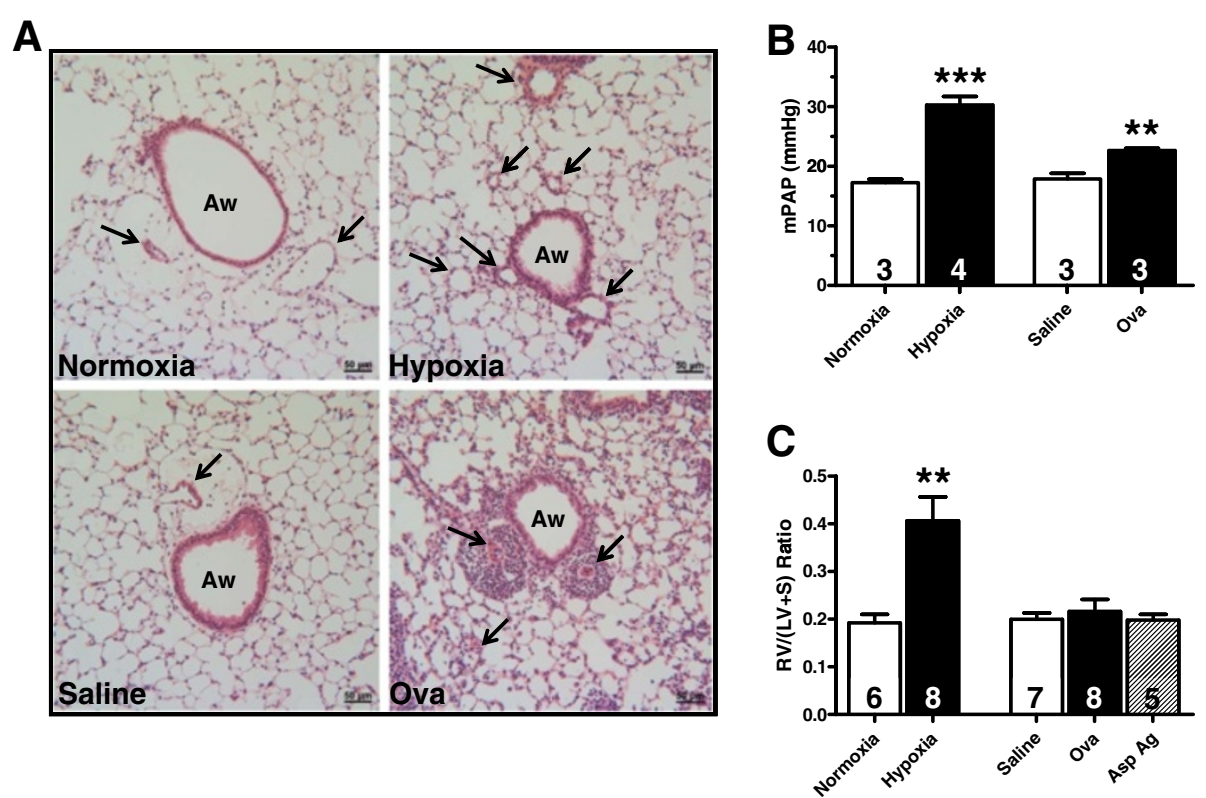

Figure 1 Chronic hypoxia- and antigen-induced pulmonary vascular remodeling. (A) Paraffin-embedded lung sections from normoxic (28 days, $20.8 \% \mathrm{O}_{2}$ ), hypoxic (28 days, $10.0 \% \mathrm{O}_{2}$ ), saline-challenged, and ovalbumin (Ova)-challenged mice were rehydrated and stained with hematoxylin and eosin. Arrows: pulmonary vessels. Aw: airway. Scale bar: $50 \mu \mathrm{m}$. (B) Mean pulmonary artery pressure (mPAP) in mice exposed to normoxia, hypoxia, saline challenge, and Ova challenge. (C) Ratio of right ventricular (RV) weight to left ventricular plus septum (LV+S) weight $[R V /(L V+S)]$ in mice exposed to normoxia, hypoxia, saline challenge, Ova challenge, and Aspergillus fumingatus antigen (Asp ag) challenge. Data are shown as means $\pm \mathrm{SEM}$. The number of mice studied is indicated within each bar. ${ }^{* *} P<0.01,{ }^{* *} P<0.001$ versus control. 
airways. In addition, massive numbers of inflammatory cells surrounded and invaded the adventitia of the remodeling blood vessels. Mice challenged with Asp ag displayed a similar pattern of vascular remodeling and inflammation to that of Ova-challenged mice (data not shown). Saline-challenged mice displayed normal pulmonary histology (Figure 1A).

\section{Effect of chronic hypoxia and Th2 inflammation on indicators of $\mathrm{PH}$}

Mice exposed to chronic hypoxia for 28 days had an elevated mPAP ( 1.75-fold) compared to normoxic controls (hypoxia: $30.29 \pm 1.44 \mathrm{mmHg}$ vs. normoxia: $17.23 \pm$ $0.57 \mathrm{mmHg} ; P<0.001$; Figure 1B). Further analysis revealed that animals exposed to hypoxia had a $\sim 2.1$-fold increase in $\mathrm{RV} /(\mathrm{LV}+\mathrm{S})$ ratio $(0.407 \pm 0.050)$ compared to normoxic controls $(0.192 \pm 0.018$; Figure $1 C)$. In a separate experiment, mice that were challenged with intranasal Ova exhibited a slight ( 1.3-fold) increase in mPAP compared to mice challenged with saline (Ova challenge: $22.65 \pm 0.37 \mathrm{mmHg}$ vs. saline: $17.88 \pm 0.94$ mmHg; $P<0.01$; Figure $1 \mathrm{~B})$. Even though mPAP increased slightly in the Ova-challenged mice, there were no changes in $\mathrm{RV} /(\mathrm{LV}+\mathrm{S})$ ratio when compared to saline-challenged controls (Ova challenge: $0.216 \pm$ 0.025 ; saline: $0.200 \pm 0.013$; Figure $1 C)$. Asp ag challenge also failed to produce a change in $\mathrm{RV} /(\mathrm{LV}+\mathrm{S})$ ratio $(0.198 \pm 0.012$; Figure $1 C)$.

\section{Evaluation of chronic hypoxia- and Th2 inflammation- induced pulmonary vascular remodeling}

In mice exposed to chronic hypoxia, muscularization of the small pulmonary vessels was increased over the course of the experiment (Figure 2). After exposure to $10.0 \% \mathrm{O}_{2}$ for 28 days, the percentage of $F M$ vessels was increased $(27.76 \pm 4.48 \%$ vs. $8.25 \pm 3.37 \% ; P<0.05$; Figure 2D), while the percentage of $\mathrm{NM}$ vessels decreased $(31.58 \pm 5.49 \%$ vs. $64.00 \pm 12.28 \% ; P<0.05)$ compared to control animals exposed to normoxia (Figure 2B). Examination of the lung sections from Ovachallenged mice revealed no significant increases in new muscularization (Figure 2B-D). Similar results were observed following Asp ag challenge (NM: $46.72 \pm$ 5.49\%: PM: $32.71 \pm 3.14 \%$; FM: $21.26 \pm 3.66 \%$ ).
A

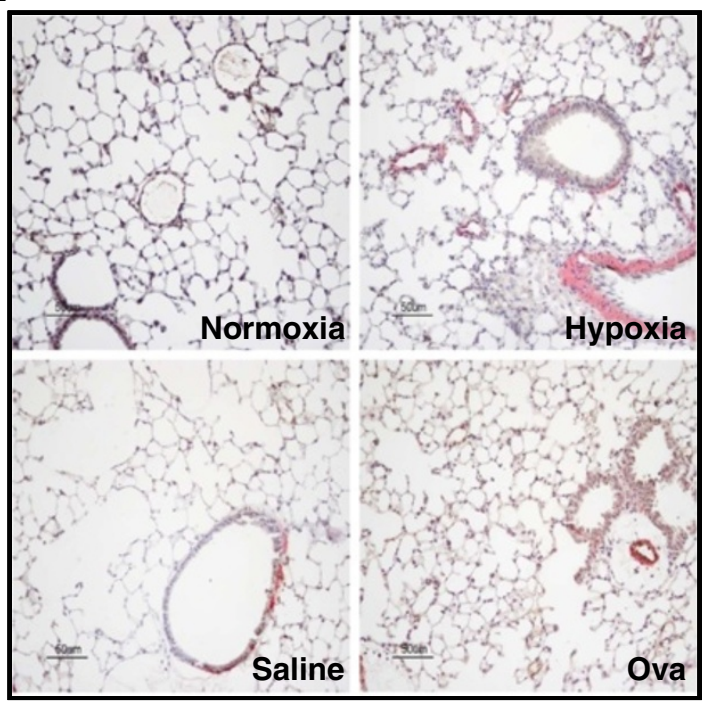

B

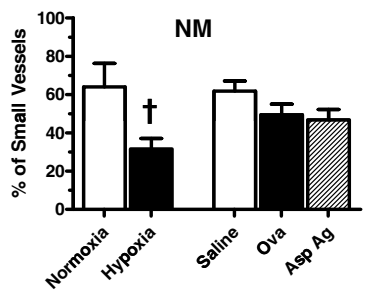

C

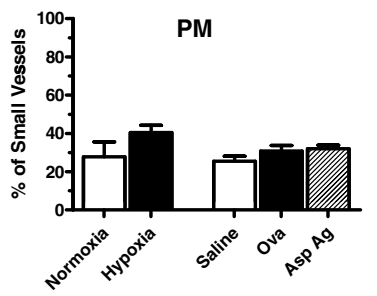

D

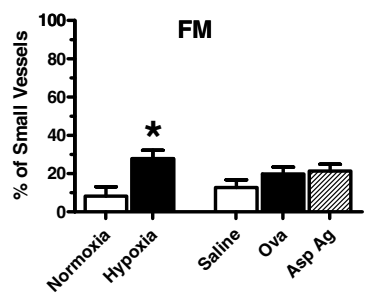

Figure 2 Evaluation of chronic hypoxia- and antigen-induced muscularization of small pulmonary vessels. (A) Paraffin-embedded lung sections from normoxic (28 days, 20.8\% $\mathrm{O}_{2}$ ), hypoxic (28 days, 10.0\% $\mathrm{O}_{2}$ ), saline-challenged, Ova-challenged, and Asp ag-challenged mice were rehydrated and double-stained with antibodies to von Willebrand factor (black) and a-smooth muscle actin (red). Sections were counterstained with hematoxylin (blue). Scale bar: 50 um. (B-D) Percent muscularization of small pulmonary vessels in mouse lung. NM, non-muscularized (B); PM, partially muscularized (C); FM, fully muscularized. $n \geq 3$ mice for each group. ${ }^{\dagger}$ Significantly decreased versus control at $P<0.05$. ${ }^{*}$ Significantly increased versus control at $P<0.05$. 
Histological representation of tissue from mice exposed to chronic hypoxia and Ova challenge is shown in Figure 2A.

The \%MT of pulmonary vessels was increased in mice exposed to chronic hypoxia compared to that of normoxic controls (Figure 3). Hypoxia increased the \%MT of intraalveolar vessels from $16.67 \pm 0.90 \%$ to $34.29 \pm 1.60 \%$ (Figure 3B) and of peribronchial vessels from $20.23 \pm 2.36 \%$ to $34.81 \pm 1.60 \%$ (Figure 3C). Hypoxia increased the thickness of both types of vessels in a similar fashion. Although Ova-challenged mice did not display significant new muscularization of small pulmonary arteries, these challenges had a profound effect on hypertrophy/hyperplasia of the already muscularized peribronchial vessels within the lung (Figure $3 \mathrm{C}$ ). When vessels associated with large airways were compared, \%MT increased from 22.01 $\pm 0.92 \%$ in saline controls to $34.53 \pm 1.35 \%$ following Ova challenge, increases very similar to those observed in pulmonary vessels from hypoxia-exposed mice. Ova challenge had virtually no effect on the \%MT of intra-alveolar vessels (Ova: $19.09 \pm 0.77 \%$ vs. saline: $18.43 \pm 0.58 \%$; Figure $3 \mathrm{~B}$ ).

\section{Genomic analysis of lung tissue}

To determine if there were genes that were mutually regulated by both chronic hypoxia and Th2 inflammation, we performed genomic analysis of RNA isolated from lung tissue from mice exposed to both models. In chronic hypoxia experiments, mice were exposed to either hypoxia $(10.0 \%$ $\left.\mathrm{O}_{2}\right)$ or room air $\left(20.8 \% \mathrm{O}_{2}\right)$ for 4 days. To gain a more complete look at pulmonary Th2 inflammation, we performed genomic analysis on lung tissue from both Ova- and Asp ag-challenged mice collected at the conclusion of these experiments. Microarray analysis revealed that 36 transcripts were significantly upregulated in all three murine models (data not shown). Of those genes, ten were related to $\mathrm{PH}$ and/or pulmonary injury (Figure 4). Interestingly, of these ten transcripts, HIMF was the most consistently upregulated in all experimental groups. Of the ten genes related to $\mathrm{PH}$ and/or pulmonary injury, all could potentially be involved in pulmonary vascular remodeling (Figure 4). One such gene was chemokine ( $\mathrm{C}-\mathrm{C}$ motif) ligand 8 ( $\mathrm{Ccl} 8$, also known as MCP-2), which may be involved in the recruitment of inflammatory cells to the pulmonary vasculature (Table 1 ). We also observed the upregulation of elastin, tenascin $\mathrm{C}$, tissue inhibitor of matrix metalloproteinase 1 (TIMP1), solute carrier family 26, member 4 (Slc26a4), matrix metalloproteinase 2 (MMP2), erythroid associated factor (ERAF), cathepsin $\mathrm{K}$, and triggering receptor expressed on myeloid cells 2 (Trem2), which are known to be involved in tissue remodeling (Table 1).

\section{Evaluation of HIMF expression}

Since HIMF was consistently upregulated in both chronic hypoxia and Th2 inflammation, we therefore

\section{A}

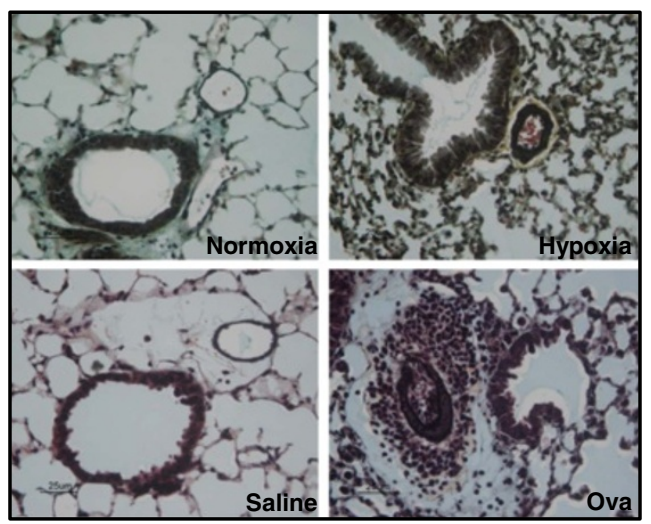

Intra-alveolar

B
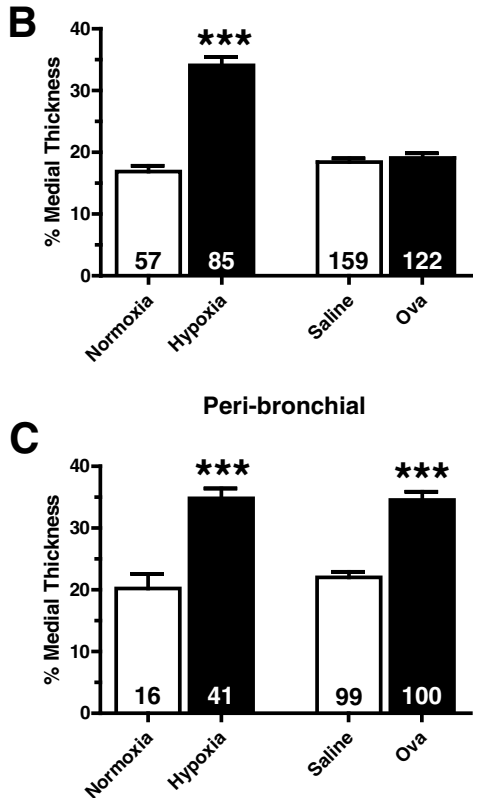

Figure 3 Evaluation of chronic hypoxia- and Ova-induced increases in percent of medial thickness (\%MT) in pulmonary vessels.

(A) Paraffin-embedded lung sections from normoxic (28 days, 20.8\% $\mathrm{O}_{2}$ ), hypoxic (28 days, $10.0 \% \mathrm{O}_{2}$ ), saline-challenged, and Ova-challenged mice were rehydrated and stained with Movat's pentachrome stain. Scale bar: $25 \mu \mathrm{m}$. Intra-alveolar (B) and peribronchial (C) \%MT in mice exposed to normoxia, hypoxia, saline challenge, and Ova challenge. Data are shown as means \pm SEM. The number of vessels counted is indicated within each bar. $\mathrm{n} \geq 4$ mice for each group. ${ }^{* *} P<0.001$ versus control. 


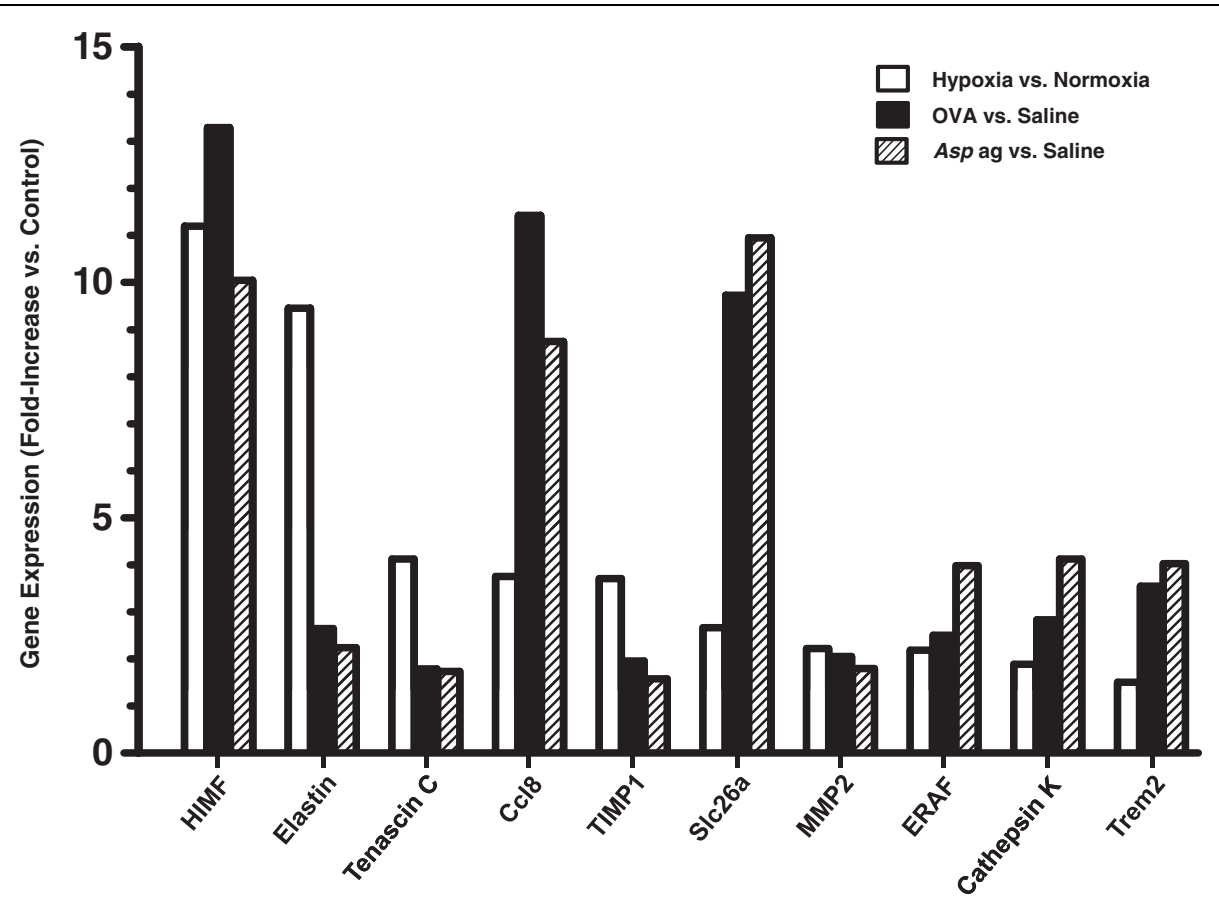

Figure $\mathbf{4}$ Genomic analysis of lung tissue from mice exposed to chronic hypoxia and antigen challenge. Lung tissue samples from normoxia (4 days, $20.8 \% \mathrm{O}_{2}$, hypoxia (4 days, 10.0\% $\mathrm{O}_{2}$ ), saline-challenged, Ova-challenged, and Asp ag-challenged mice were processed for cDNA microanalysis. Data are displayed as the mean of the fold-increase versus simultaneous control (normoxia or saline-challenge). $n \geq 3$ mice for each group. HIMF: hypoxia-induced mitogenic factor; Ccl8: chemokine (C-C motif) ligand 8; TIMP1: tissue inhibitor of metalloproteinases 1; SIc26a4: solute carrier family 26, member 4; MMP2: matrix metalloproteinase-2; ERAF: erythroid associated factor; Trem2: triggering receptor expressed on myeloid cells 2.

examined its expression patterns in both models. HIMF expression was increased in the BALF (Figure 5A) and in whole lung lysates (Figure $5 \mathrm{~B}$ ) from mice exposed to chronic hypoxia (4 days) or Ova challenge. Immunohistochemical analysis of HIMF in these groups revealed differential expression patterns in each (Figure 5C). In chronic hypoxia, HIMF was expressed throughout the lung and was upregulated in airway epithelium, alveolar type II cells, vascular smooth muscle cells, endothelium, and inflammatory cells. It was noticeably upregulated in both peribronchial and intra-alveolar vessels. Ova challenge induced HIMF expression mainly in airway epithelium and inflammatory cells; HIMF expression was noticeably absent from vascular smooth muscle and endothelium in all areas of the lungs of these mice (Figure 5C).

\section{Cellular localization of HIMF}

To determine which specific cell types in the lung express HIMF after chronic hypoxia or Ova challenge and which inflammatory cells are recruited to the lung, we performed immunofluorescence co-localization to compare HIMF expression with the expression of cellspecific markers. Similar to the immunochemistry results, the lungs from mice exposed to chronic hypoxia displayed HIMF-specific immunofluorescence in airway epithelium, pulmonary vasculature, and inflammatory cells; lungs from the Ova-challenged mice had increased HIMF expression in airway epithelium and inflammatory cells (Figures 6, 7, 8 and 9). More specifically, HIMF signal co-localized with $\alpha$-smooth muscle actin signal following chronic hypoxia (Figure 6D). HIMF and $\alpha-$ smooth muscle actin did not co-localize in the lung sections prepared from Ova-challenged mice (Figure 6H). Interestingly, several HIMF-positive cells were located in close proximity to the vasculature in both chronic hypoxia and Ova challenge models. These HIMF-positive cells were a mixture of macrophages (marker, F4/80; Figure 7), neutrophils (marker, neutrophil marker; Figure 8), and T-cells (marker, CD3; Figure 9). These inflammatory cells were much more prominent around the remodeling vasculature after Ova challenge than after chronic hypoxia. Almost all of the remodeled vessels in Ova-challenged mice were surrounded by a mixture of these HIMF-expressing inflammatory cells, and the overall number of inflammatory cells was large; only a few vessels from the chronic hypoxia model had these HIMF-expressing cells clustered around the vasculature, and the overall number of inflammatory cells was small following this stimulus. Further analysis revealed that B-cells (marker, CD19) and eosinophils (marker, MBP) 
Table 1 Commonly upregulated genes

\begin{tabular}{|c|c|c|}
\hline Gene & Potential function in $\mathrm{PH}$ & References \\
\hline \multirow[t]{4}{*}{ HIMF } & endothelial cell proliferation & {$[10,14,20,21,29]$} \\
\hline & smooth muscle cell proliferation & \\
\hline & vasoconstriction & \\
\hline & inflammation & \\
\hline Elastin & tissue remodeling & [43-45] \\
\hline \multirow[t]{2}{*}{ Tenascin C } & smooth muscle cell proliferation & [46-49] \\
\hline & potential PH biomarker & \\
\hline Ccl8 & inflammation & {$[50]$} \\
\hline TIMP1 & tissue remodeling & {$[51]$} \\
\hline \multirow[t]{3}{*}{ Slc26a4 } & inflammation & {$[52,53]$} \\
\hline & mucus secretion & \\
\hline & airway hyperreactivity & \\
\hline \multirow[t]{2}{*}{ MMP2 } & tissue remodeling & {$[49,54]$} \\
\hline & potential PH biomarker & \\
\hline ERAF & potential PH biomarker & {$[55]$} \\
\hline Cathepsin K & tissue remodeling & {$[56,57]$} \\
\hline Trem2 & inflammation & {$[58]$} \\
\hline
\end{tabular}

were also present in the mixture of inflammatory cells surrounding vessels following Ova challenge, but these cells did not express HIMF in our model system (data not shown). Neither cell type was prominently present in the chronic hypoxia model (data not shown).

\section{Discussion}

The current study demonstrates that both chronic hypoxia and repeated airway antigen challenges induce pulmonary vascular remodeling in adult male C57BL/6 mice; however, differences were apparent in the types and extent of remodeling. Exposure to chronic hypoxia for 28 days increased all of the indicators of $\mathrm{PH}$ that we examined in this study [mPAP, $\mathrm{RV} /(\mathrm{LV}+\mathrm{S})$ ratio, vascular remodeling]. In contrast to Ova-challenged mice, hypoxic mice exhibited marked increases in both MPAP and $\mathrm{RV} /(\mathrm{LV}+\mathrm{S})$ ratio. In addition, mice exposed to chronic hypoxia exhibited an overall neo-muscularization of the pulmonary vessels throughout the entire lung in which both intra-alveolar and peribronchial vessels were thickened. The vessels from this model had the appearance of concentric remodeling. At the 28-day time point, there was little apparent perivascular inflammation. Several recent reports have suggested that Th2 inflammation is involved in the pulmonary vascular remodeling associated with the development of $\mathrm{PH}[6,13,15-18,59]$; therefore, we employed extended Ova-and Asp agchallenge models (3 challenges/week, 4 weeks) to ellicit this response. Analysis of the parameters for $\mathrm{PH}$ revealed a slight, but statistically significant increase in mPAP ( 1.3-fold) compared to saline control but no change in $\mathrm{RV} /(\mathrm{LV}+\mathrm{S})$ ratio compared to salinechallenged mice. As expected, extended intranasal Ova
A

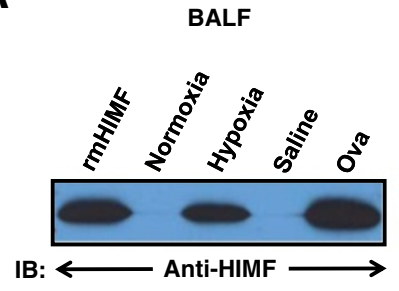

B

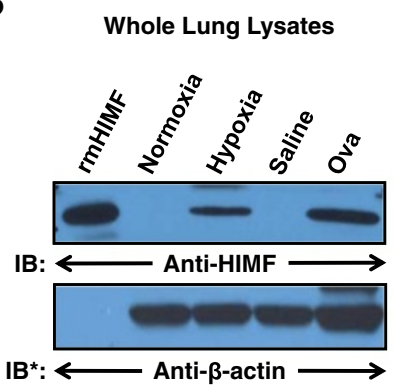

C

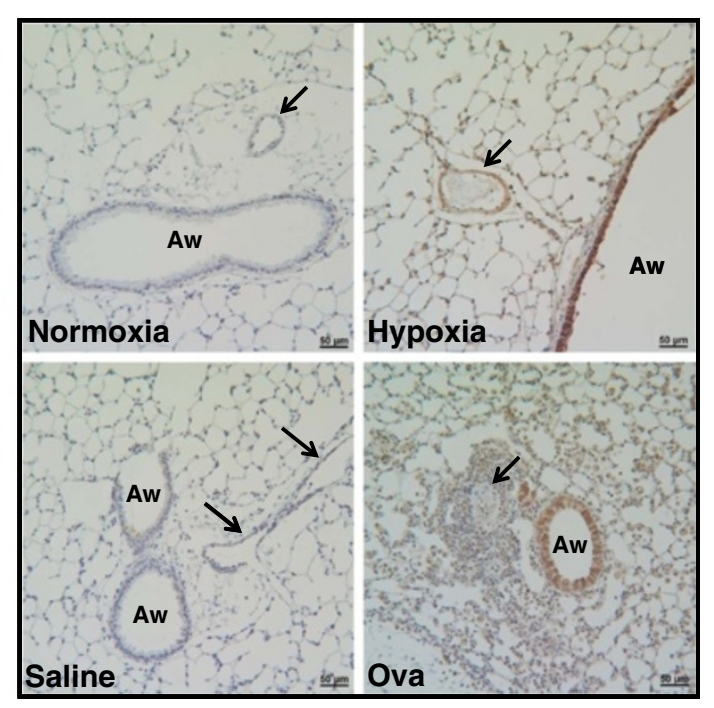

Figure 5 Expression pattern of hypoxia-induced mitogenic factor (HIMF) following chronic hypoxia or Ova challenge.

(A) Bronchioalveolar lavage fluid (BALF) and (B) whole-lung homogenates from normoxic (4 days, 20.8\% $\mathrm{O}_{2}$ ), hypoxic $\left(4\right.$ days, $10.0 \% \mathrm{O}_{2}$ ), salinechallenged, and Ova-challenged mice were resolved by 4-20\% SDS-PAGE and transferred to nitrocellulose. The blots were probed with rabbit anti-HIMF antibodies and developed using enhanced chemiluminescence. To confirm equal loading and transfer, the blots were stripped and reprobed with $\beta$-actin monoclonal antibodies. IB, immunoblot; IB*, immunoblot after stripping. (C) Paraffin-embedded lung sections from normoxic, hypoxic, saline-challenged, and Ova-challenged mice were rehydrated and stained with antibodies raised against HIMF (brown). Sections were counterstained with hematoxylin (blue). Aw: airway. Arrows: small pulmonary vessels. Scale bar: $50 \mu m$. 


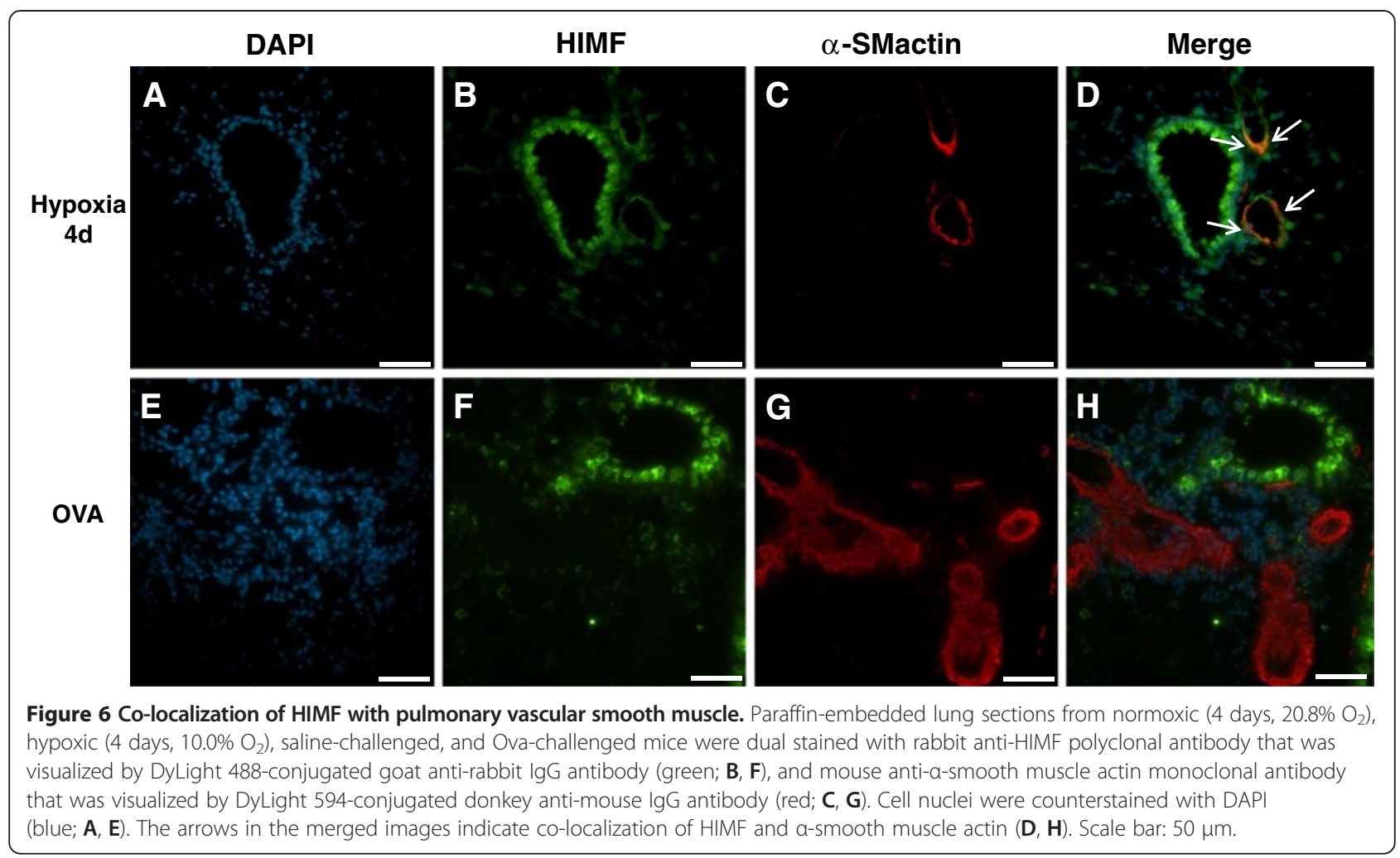

challenges produced large amounts of pulmonary inflammation, particularly around the peribronchial vessels, but little new muscularization of peripheral pulmonary vessels; specific analysis of the medial thickness of both intra-alveolar and peribronchial vessels revealed extensive hypertrophy/hyperplasia in only the peribronchial vessels. The remodeling that we observed in peribronchial vessels looked very different from remodeled vessels in the hypoxic mice; the vessels from Ova-challenged mice appeared to have disorganized hypertrophy/hyperplasia.

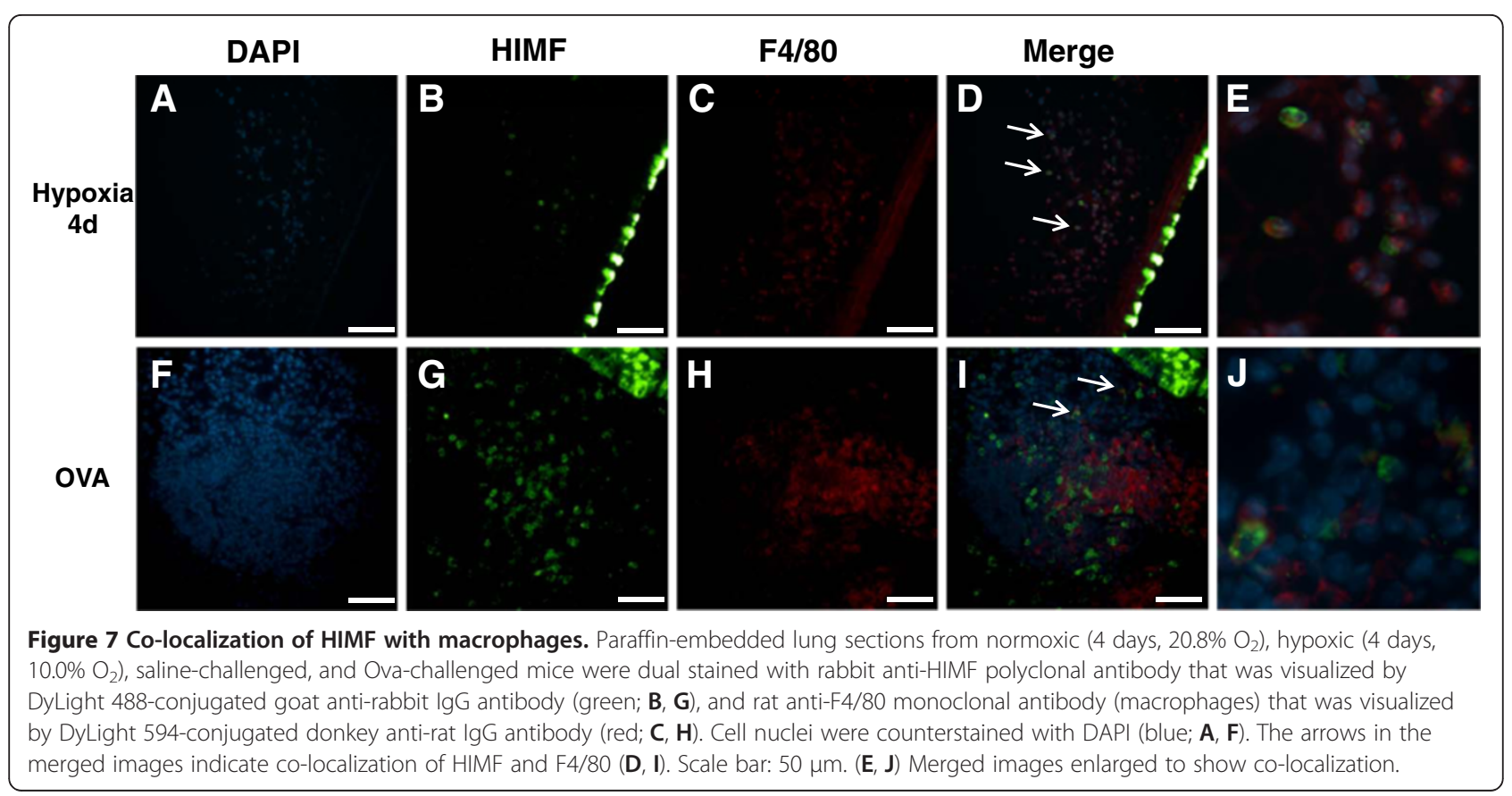




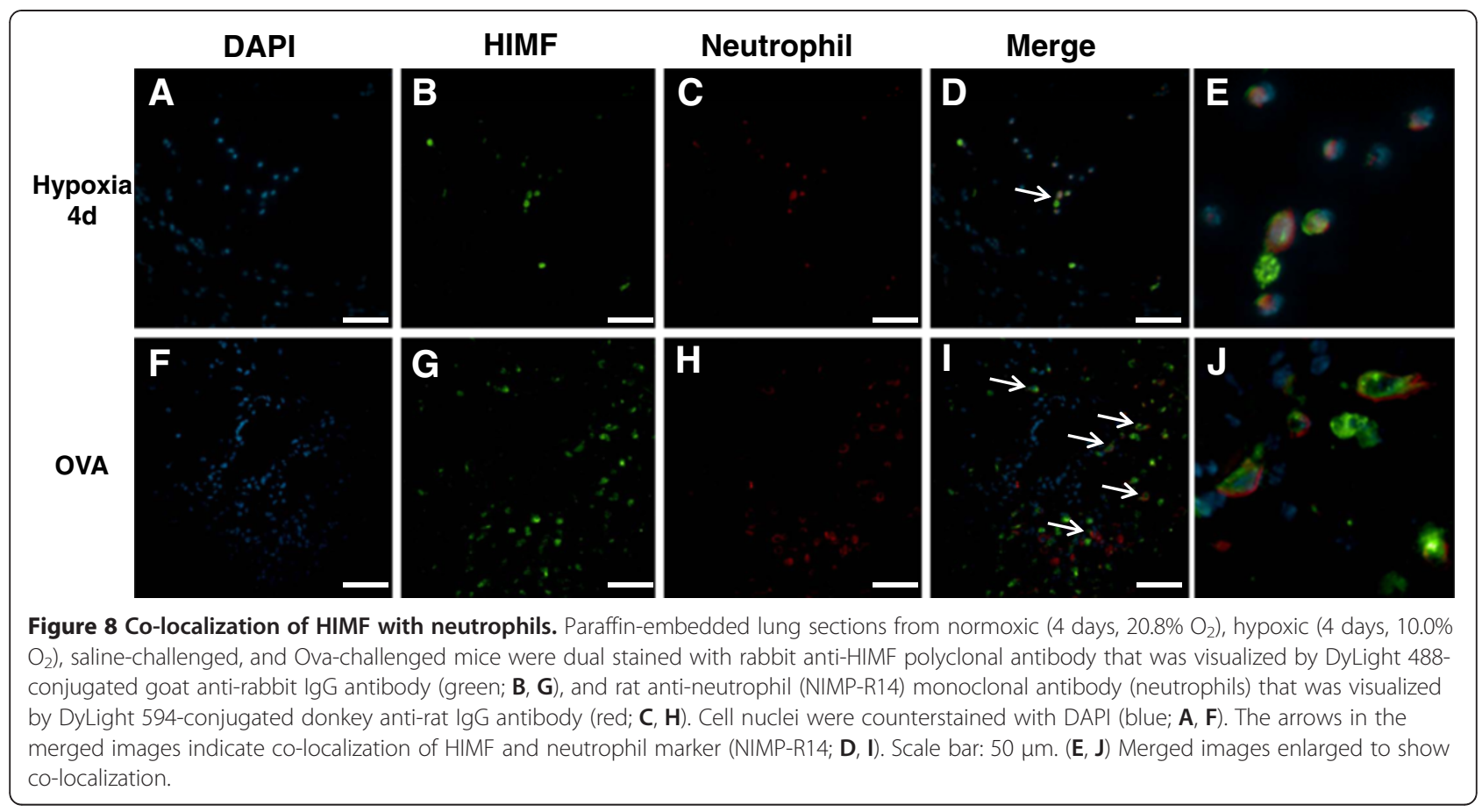

Also, the vessels that appeared to be the most remodeled had the most HIMF-expressing inflammatory cells associated with them.

Several Th2 inflammatory models of pulmonary vascular remodeling have been developed in recent years (e.g., Ova-challenge, S. mansoni infection), but these models have limitations regarding the development of
PH. As opposed to chronic hypoxia, in which experimental animals consistently display elevated pulmonary and RV pressures, Th2 inflammatory models display little or no pulmonary pressure change $[15,19,60]$. In the current study, chronic hypoxia induced an almost twofold increase in both mPAP and RV/(LV+S). Although we did observe a mild increase in the mPAP $(\sim 1.3$-fold

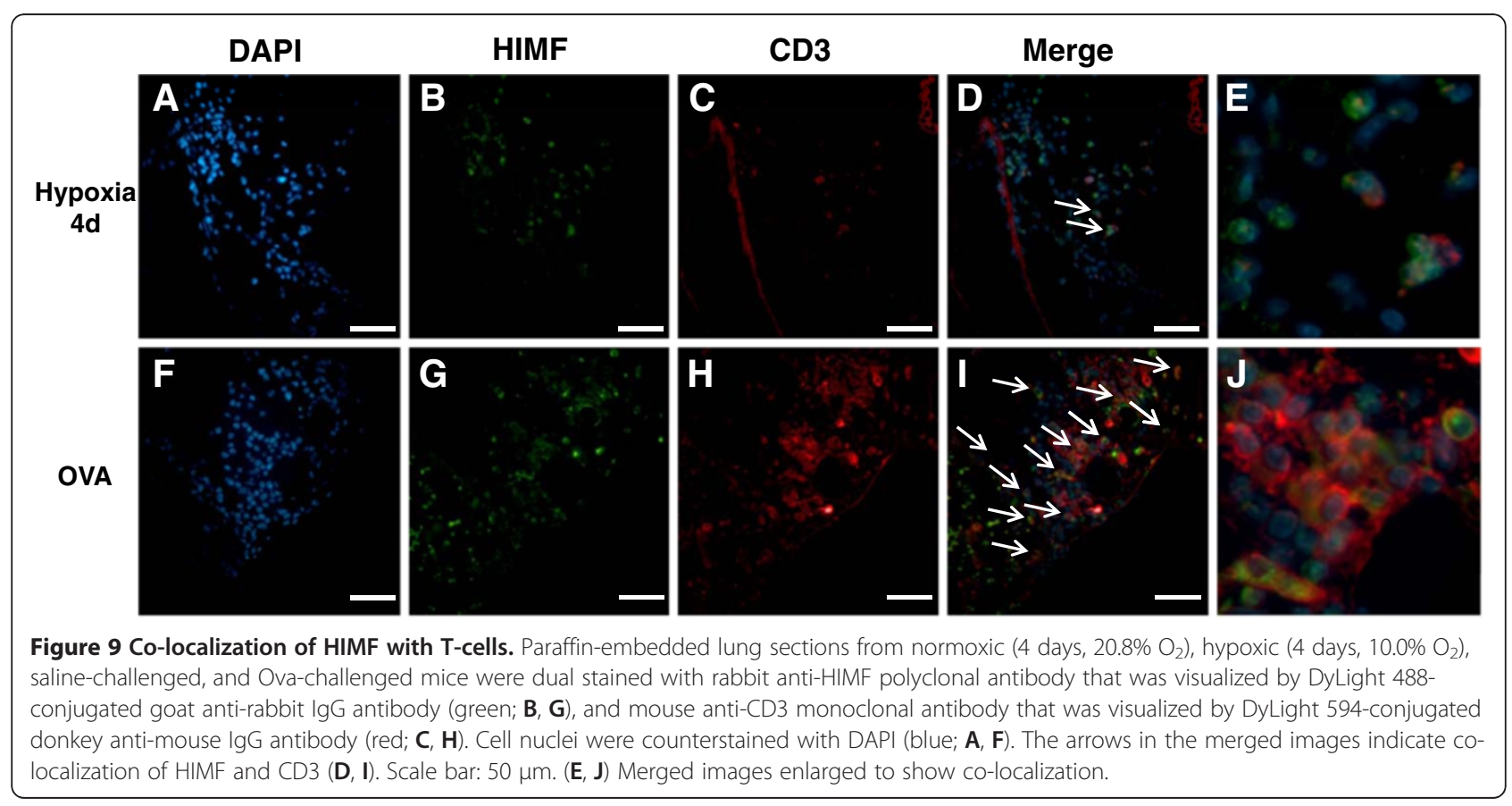


increase) of our Ova-challenged mice, this change was not accompanied by RV hypertrophy. Daley et al. [15] reported no changes in right ventricular end systolic pressure in association with antigen challenge. Crosby et al. [60] reported extensive pulmonary vascular remodeling associated with a murine model of S. mansoni infection, but these animals did not experience significant PH; the authors did suggest that MPAP was higher in those mice that had a greater and more widespread egg burden. In another study on S. mansoni infection, Graham et al. [19] also reported extensive remodeling, but demonstrated significant RV pressure increases only in IL-13R $\alpha 2$ knockout mice, not in infected wild-type mice. It is possible that elevated pulmonary pressures were not observed in these models because of the time frames used for these experiments. A follow-up study performed by Crosby et al., [61], demonstrated that $S$. mansoni infection induced pulmonary vascular remodeling, increased RV pressures, as well as RV hypertrophy at 25 weeks following initial infection. These investigators also demonstrated that the severity of the vascular remodeling correlated with the proximity of the $S$. mansoni eggs. Another long-term study performed by Mushaben et al., [62] demonstrated that chronic exposure to house dust mite antigen induced pulmonary vascular remodeling at 7 and 20 weeks of exposures. This study also demonstrated increased RV pressures at 20 weeks, but not at 7 weeks. These studies suggest that it may be possible that a chronic Th2 stimulus may be required for the development of $\mathrm{PH}$ in these models.

Immunohistochemical expression patterns of HIMF following either chronic hypoxia or Ova challenge revealed a marked difference between these two models. Most significant among these differences was the consistent expression of HIMF in the vascular endothelium and smooth muscle throughout the lung following chronic hypoxia and the complete absence of HIMF expression in the vasculature following Ova challenge. Hypoxia induced HIMF staining in airway epithelial cells, alveolar type II cells, endothelium, vascular smooth muscle, and inflammatory cells, findings consistent with data that we have previously reported in both mice and rats [20,21] as well as human PH lung [31]. Using double-labeling immunofluorescence microscopy, we also showed that HIMF co-localizes with smooth muscle cells only in the chronic hypoxia model. It is likely that a hypoxic stimulus induces smooth muscle cells within the lung to directly express HIMF, which could initiate the vascular remodeling process. This finding is consistent with our prior work in which we showed that knockdown of HIMF reduced chronic hypoxia-induced vascular remodeling [20]. We did observe that HIMF was expressed in macrophages, T-cells, and neutrophils during chronic hypoxia, but these co-localization events occurred less consistently than did HIMF co-localization with $\alpha$-smooth muscle actin. After Ova challenge, HIMF was exclusively expressed in airway epithelial cells and inflammatory cells, a finding consistent with those of previous studies that used Ova or Asp ag challenge $[15,23,27]$. The initial study by Holcomb et al. [23] demonstrated HIMF expression in alveolar type II cells following aerosolized Ova challenge in adult female BALB/c mice, but no expression in the vascular tissue. The expression pattern of HIMF is very similar in another Th2-dependent model of pulmonary vascular remodeling. Following S. mansoni infection, HIMF is also upregulated in areas surrounding the typical granulomas, but not in the remodeled vessels themselves [19]. The lack of HIMF expression in the vascular tissue during inflammation-induced remodeling would suggest that HIMF may be acting on the vasculature through an indirect process. To examine this concept, we identified the inflammatory cells that expressed HIMF after Ova challenge. We found that HIMF was expressed by several different inflammatory cell types, including macrophages, T-cells, and neutrophils, in Ova-challenged mice and that very large numbers of such cells surrounded the remodeling peribronchial blood vessels. The expression of HIMF by macrophages is consistent with previously reported data [23]. To the best of our knowledge, this is the first study to demonstrate that HIMF is expressed in neutrophils and T-cells at the site of inflammation within the lung. At the time point examined, HIMF was not expressed in eosinophils or B-cells. It is possible that HIMF is expressed by these cells [63] at a different time point or in a different mouse strain than those used for this study. We have previously demonstrated that the human homolog to HIMF, RELM $\beta$, is expressed in macrophages and T-cells as well as in vascular cells, plexiform lesions, and myofibroblasts, in patients diagnosed with scleroderma-associated $\mathrm{PH}$ [31].

The time course of HIMF expression also differs following hypoxia and antigen challenge. During chronic hypoxia, HIMF mRNA expression is maximal $24 \mathrm{~h}$ after initial hypoxic exposure [21]; HIMF protein expression peaks at 4 days of chronic hypoxia and gradually decreases until it reaches baseline levels at approximately 14 days [21]. In the mouse model, the increased HIMF expression correlates with the hyperplastic phase of lung vascular remodeling. This is also consistent with our observations that HIMF is upregulated in the vascular smooth muscle cells that are undergoing cell division [proliferating cell nuclear antigen (PCNA)- and/or Ki67-positive]. Other work from our laboratory supports this hyperplastic role for HIMF, as we have found HIMF to exert a marked shift in human mesenchymal cells to a dividing phenotype [64]. Because HIMF is primarily expressed during the early hyperplastic phase of chronic 
hypoxia and we have demonstrated that preventing such expression prevents long-term remodeling associated with chronic hypoxia [20], we hypothesize that HIMF acts as an initiating factor for pulmonary vascular remodeling. Lack of HIMF protein within the lungs at this early point of chronic hypoxia reduces the extensive remodeling that would normally result [20]. With Ova challenge, HIMF appears to be consistently upregulated throughout the time period of the model, albeit focal to the area of inflammation. Sun et al. [27] has reported increased HIMF expression following an initial 7-day Ova challenge. We and others have demonstrated extensive HIMF expression following extended Ova challenges (3 challenges/week, 4 weeks) [15,22,23,27].

It is currently unknown whether HIMF gene expression is regulated differently through hypoxia and Th2 stimulation or if changes in the two models are parallel. Evidence from sequence analysis and other published work suggests that the transcription factors CCAAT box enhancer binding protein- $\beta(\mathrm{C} / \mathrm{EBP} \beta)$, hypoxia-inducible factor- $1 \alpha$ (HIF-1 $\alpha)$, signal transducers and activators of transcription-6 (STAT6), and/or NF- $\mathrm{kB}$ may be involved in HIMF gene regulation [21,24,26,65-68]. Stutz et al. [26] demonstrated that HIMF itself is activated by the Th2 inflammatory pathway in cultured murine bone marrow cells via IL-4 and IL-13 activation of STAT6 and/or $\mathrm{C} / \mathrm{EBP} \beta$ in its promoter region. Another previous study demonstrated that bleomycin-induced pulmonary HIMF mRNA expression was partially blocked in IL-4 and IL-13 knockout mice [24]. This same study also demonstrated that combined knockout of IL-4 and IL-13 completely blocked HIMF expression in the bleomycin-injured lung. Also, the number of HIMFpositive cells located around remodeled vessels in an Asp ag-challenge model was reduced in IL-4 knockout mice compared to that in wild-type controls [15]. In $S$. mansoni infection, HIMF expression is at least partly dependent on IL-13R $\alpha 1$ [19]. Currently, not much is known about hypoxia-induced regulation of HIMF. In a recent study published by our laboratory, we demonstrated hypoxia-induced HIMF expression in both IL-4 and STAT6 knockout mice [14]. This finding would suggest that Th2 inflammation and hypoxia regulate HIMF expression through different mechanisms. This possibility is consistent with both hypoxia-related and Th2related transcription factor binding sites in the regulatory regions of the HIMF gene.

We have previously shown that HIMF has mitogenic, angiogenic, anti-apoptotic, vasoconstrictive, and chemokine-like properties both in vivo and in vitro $[10,20,21,28,29,68]$. These are key processes involved in the pathogenesis of $\mathrm{PH}$. We have demonstrated that the addition of recombinant HIMF induces a dose-dependent growth response of cultured pulmonary vascular smooth muscle cells [21], and others have shown that intratracheal instillation of HIMF induces proliferation of pulmonary vascular smooth muscle in vivo [69]. The addition of recombinant HIMF in vitro activates the phosphoinositide 3-kinase (PI-3K) as well as the extracellular signal-regulated kinase $1 / 2$ (ERK1/2) signaling pathways [21,65-67,70-72], both of which are key proliferative pathways. These signaling events occur in isolated primary cultured rodent and human pulmonary vascular smooth muscle cells, illustrating that HIMF acts directly on the cultured cells to induce proliferation; this signaling appears to occur independently of any secondary inflammatory effects that could be induced by HIMF. The differential expression that we have observed may affect the pulmonary vascular remodeling that is observed in each model. It is possible that upregulation of HIMF in both vascular smooth muscle and endothelium may contribute to an autocrine pathway in which HIMF induces cell proliferation within the vasculature. The overexpression of HIMF in the lung vasculature appears to contribute to the overall vascular remodeling of the lung that we are seeing during chronic hypoxia. We have previously shown that AAV-HIMF-induced overexpression of HIMF in the pulmonary vasculature leads to proliferation of both vascular smooth muscle and endothelial cells [20]. During Ova challenge, pulmonary vascular remodeling is localized to the vessels associated with large airways. In this model, large amounts of HIMF are produced and secreted by airway epithelial and inflammatory cells, but no HIMF is expressed in the pulmonary vasculature itself. It is reasonable to suggest that the HIMF secreted into the surrounding areas of the lung affects the local pulmonary vessels and thereby drives the localized remodeling. Daley et al. [15] reported that in an Asp ag-challenge model, HIMF was expressed in areas surrounding remodeled vessels similar to what we have observed in our Ova-challenge model. The smooth muscle cells in these remodeled vessels also express the markers for cellular proliferation, Ki67 and PCNA [15].

\section{Conclusions}

Our results demonstrate that pulmonary vascular remodeling in mice induced by chronic hypoxia or antigen sensitization and challenge is associated with marked increases in HIMF expression both at the message and protein levels. HIMF was upregulated in the airway epithelium and inflammatory cells in both models, although it was expressed in the vascular smooth muscle of the hypoxia model only. It is certainly possible that the expression of HIMF within the pulmonary vessels themselves may lead to more robust vascular remodeling; 
therefore, leading to increased pulmonary pressure and right heart hypertrophy. Taken together, our data suggest that HIMF is a key factor in the etiology of both hypoxia- and inflammation-induced models of pulmonary vascular remodeling.

\begin{abstract}
Abbreviations
PH: Pulmonary hypertension; mPAP: Mean pulmonary artery pressure; HIV: Human immunodeficiency virus; COPD: Chronic obstructive pulmonary disease; PVR: Pulmonary vascular resistance; RV: Right ventricle; LV: Left ventricle; Th1: T-helper 1; Th2: T-helper 2; Ova: Ovalbumin; Asp ag: Aspergillus fumigatus antigen; S. mansoni: Shistosoma mansoni; HIMF: Hypoxia-induced mitogenic factor; FIZZ1: Found in inflammatory zone 1; RELMa: Resistin-like molecule alpha; RELMB: Resistin-like molecule beta; SDF-1: Stromal cellderived factor-1; MCP-1: Monocyte chemoattractant protein-1; IL4: Interleukin-4; IL-6: Interleukin-6; IL-13: Interleukin-13; HHV8: Human herpes virus 8; BALF: Bronchalveolar lavage fluid; H\&E: Hematoxylin \& eosin NM: Non-muscular; PM: Partially-muscular; FM: Fully-muscular; \%MT: \% of medial thickness; PB: Peri-bronchial; IA: Intra-alveolar; HRP: Horseradish peroxidase; TBS-T: Tris-buffered saline with 0.1\% Tween 20; DAB: 3,3'diaminobenzidine; SEM: Standard error of mean; PCNA: Proliferating cell nuclear antigen; DAPI: 4',6'-diamidino-2-phenylindole dilactate; GSMA: Gene Set Matrix Analysis; C/EBPB: CCAAT box enhancer binding protein- $\beta$; HIF1a: Hypoxia-inducible factor-1a; STAT6: Signal transducers and activators of transcription-6; PI-3K: Phosphoinositide 3-kinase; ERK: Extracellular signalregulated kinase.
\end{abstract}

\section{Competing interests}

The author(s) declare that they have no competing interests.

\section{Authors' contributions}

The experiments were conceived and designed by DJA and RAJ. The experiments were carried out by DJA, QS, KYK, CF, JTS, AP, CC, and HE. DJA, $\mathrm{KYK}, \mathrm{CF}, \mathrm{CC}$, and RAJ analyzed the data. RAJ contributed reagents/materials/ analysis tools for the experiments. DJA, KYK, and RAJ were involved in the writing of the manuscript. All authors have read and approve of this manuscript.

\section{Acknowledgements}

This work was supported by NIH SCCOR P50 084946 (RAJ), NIH NHLBI R01 39706 (RAJ), and NIH fellowship T32 GM075774-09 (DJA). The authors thank Ms. Claire Levine for critical review and assistance with the manuscript preparation. We also thank Ms. Dea Sloan, Ms. Diana Zhu, and Mr. Noah Weiner for technical assistance.

\section{Author details}

'Department of Anesthesiology and Critical Care Medicine, Johns Hopkins University School of Medicine, 720 Rutland Avenue, Ross 361, Baltimore, MD 21205, USA. Division of Cardiology, Department of Medicine, Johns Hopkins University School of Medicine, Baltimore, MD 21205, USA. ${ }^{3}$ Division of Allergy and Clinical Immunology, Department of Medicine, Johns Hopkins University School of Medicine, Baltimore, MD 21205, USA. ${ }^{4}$ Division of Pulmonary and Critical Care Medicine, Department of Medicine, Johns Hopkins University School of Medicine, Baltimore, MD 21205, USA.

Received: 24 April 2012 Accepted: 12 December 2012 Published: 4 January 2013

\section{References}

1. Badesch DB, Champion HC, Sanchez MA, Hoeper MM, Loyd JE, Manes A, McGoon M, Naeije R, Olschewski H, Oudiz RJ, Torbicki A: Diagnosis and assessment of pulmonary arterial hypertension. J Am Coll Cardiol 2009, 54:S55-S66.

2. Simonneau G, Galie N, Rubin LJ, Langleben D, Seeger W, Domenighetti G, Gibbs S, Lebrec D, Speich R, Beghetti M, et al: Clinical classification of pulmonary hypertension. J Am Coll Cardiol 2004, 43:5S-12S.

3. Graham BB, Bandeira AP, Morrell NW, Butrous G, Tuder RM: Schistosomiasis-associated pulmonary hypertension: pulmonary vascular disease: the global perspective. Chest 2010, 137:20S-29S.
4. Humbert M, Sitbon $\mathrm{O}$, Simonneau G: Treatment of pulmonary arterial hypertension. N Engl J Med 2004, 351:1425-1436.

5. Chan SY, Loscalzo J: Pathogenic mechanisms of pulmonary arterial hypertension. J Mol Cell Cardiol 2008, 44:14-30.

6. Dorfmuller P, Perros F, Balabanian K, Humbert M: Inflammation in pulmonary arterial hypertension. Eur Respir J 2003, 22:358-363.

7. Kherbeck N, Tamby MC, Bussone G, Dib H, Perros F, Humbert M, Mouthon $L$ : The role of inflammation and autoimmunity in the pathophysiology of pulmonary arterial hypertension. Clin Rev Allergy Immunol 2011, [Epub ahead of print].

8. Jeffery TK, Morrell NW: Molecular and cellular basis of pulmonary vascular remodeling in pulmonary hypertension. Prog Cardiovasc Dis 2002, 45:173-202.

9. Tuder RM, Marecki JC, Richter A, Fijalkowska I, Flores S: Pathology of pulmonary hypertension. Clin Chest Med 2007, 28:23-42. vii.

10. Angelini DJ, Su Q, Kolosova IA, Fan C, Skinner JT, Yamaji-Kegan K, Collector M, Sharkis SJ, Johns RA: Hypoxia-induced mitogenic factor (HIMF/FIZZ1/ RELM alpha) recruits bone marrow-derived cells to the murine pulmonary vasculature. PLoS One 2010, 5:e11251.

11. Burke DL, Frid MG, Kunrath CL, Karoor V, Anwar A, Wagner BD, Strassheim D, Stenmark KR: Sustained hypoxia promotes the development of a pulmonary artery-specific chronic inflammatory microenvironment. Am J Physiol Lung Cell Mol Physiol 2009, 297:L238-L250.

12. Frid MG, Li M, Gnanasekharan M, Burke DL, Fragoso M, Strassheim D, Sylman JL, Stenmark KR: Sustained hypoxia leads to the emergence of cells with enhanced growth, migratory, and promitogenic potentials within the distal pulmonary artery wall. Am J Physiol Lung Cell Mol Physiol 2009, 297:L1059-L1072.

13. Yamaji-Kegan K, Su Q, Angelini DJ, Johns RA: IL-4 is proangiogenic in the lung under hypoxic conditions. J Immunol 2009, 182:5469-5476.

14. Yamaji-Kegan K, Su Q, Angelini DJ, Myers AC, Cheadle C, Johns RA: Hypoxia-induced mitogenic factor (HIMF/FIZZ1/RELMalpha) increases lung inflammation and activates pulmonary microvascular endothelial cells via an IL-4-dependent mechanism. J Immunol 2010, 185:5539-5548,

15. Daley E, Emson C, Guignabert C, de Waal Malefyt R, Louten J, Kurup VP, Hogaboam C, Taraseviciene-Stewart L, Voelkel NF, Rabinovitch M: Pulmonary arterial remodeling induced by a Th2 immune response. J Exp Med 2008, 205:361-372.

16. Johns RA: Th2 inflammation, hypoxia-induced mitogenic factor/FIZZ1, and pulmonary hypertension and vascular remodeling in schistosomiasis. Am J Respir Crit Care Med 2010, 181:203-205.

17. Swain SD, Han S, Harmsen A, Shampeny K, Harmsen AG: Pulmonary hypertension can be a sequela of prior Pneumocystis pneumonia. Am J Pathol 2007, 171:790-799.

18. Tormanen KR, Uller L, Persson CG, Erjefalt JS: Allergen exposure of mouse airways evokes remodeling of both bronchi and large pulmonary vessels. Am J Respir Crit Care Med 2005, 171:19-25.

19. Graham BB, Mentink-Kane MM, El-Haddad H, Purnell S, Zhang L, Zaiman A Redente EF, Riches DW, Hassoun PM, Bandeira A, et al: Schistosomiasisinduced experimental pulmonary hypertension: role of interleukin-13 signaling. Am J Pathol 2010, 177:1549-1561.

20. Angelini DJ, Su Q, Yamaji-Kegan K, Fan C, Skinner JT, Champion HC, Crow MT, Johns RA: Hypoxia-induced mitogenic factor (HIMF/FIZZ1/RELMalpha) induces the vascular and hemodynamic changes of pulmonary hypertension. Am J Physiol Lung Cell Mol Physiol 2009, 296:L582-L593.

21. Teng X, Li D, Champion HC, Johns RA: FIZZ1/RELMalpha, a novel hypoxiainduced mitogenic factor in lung with vasoconstrictive and angiogenic properties. Circ Res 2003, 92:1065-1067.

22. Dong L, Wang SJ, Camoretti-Mercado B, Li HJ, Chen M, Bi WX: FIZZ1 plays a crucial role in early stage airway remodeling of OVA-induced asthma. J Asthma 2008, 45:648-653.

23. Holcomb IN, Kabakoff RC, Chan B, Baker TW, Gurney A, Henzel W, Nelson C, Lowman HB, Wright BD, Skelton NJ, et al: FIZZ1, a novel cysteine-rich secreted protein associated with pulmonary inflammation, defines a new gene family. EMBO J 2000, 19:4046-4055.

24. Liu T, Jin H, Ullenbruch M, Hu B, Hashimoto N, Moore B, McKenzie A, Lukacs NW, Phan SH: Regulation of found in inflammatory zone 1 expression in bleomycin-induced lung fibrosis: role of IL-4/IL-13 and mediation via STAT-6. J Immunol 2004, 173:3425-3431.

25. Mora AL, Torres-Gonzalez E, Rojas M, Corredor C, Ritzenthaler J, Xu J, Roman J, Brigham K, Stecenko A: Activation of alveolar macrophages via the 
alternative pathway in herpesvirus-induced lung fibrosis. Am J Respir Cell Mol Biol 2006, 35:466-473.

26. Stutz AM, Pickart LA, Trifilieff A, Baumruker T, Prieschl-Strassmayr E, Woisetschlager M: The Th2 cell cytokines IL-4 and IL-13 regulate found in inflammatory zone $1 /$ resistin-like molecule alpha gene expression by a STAT6 and CCAAT/enhancer-binding protein-dependent mechanism. J Immunol 2003, 170:1789-1796.

27. Sun Y, Wang J, Li H, Han X: Found in inflammatory zone 1 induces angiogenesis in murine models of asthma. Lung 2008, 186:375-380.

28. Su Q, Zhou Y, Johns RA: Bruton's tyrosine kinase (BTK) is a binding partner for hypoxia induced mitogenic factor (HIMF/FIZZ1) and mediates myeloid cell chemotaxis. FASEB J 2007, 21:1376-1382.

29. Yamaji-Kegan K, Su Q, Angelini DJ, Champion HC, Johns RA: Hypoxiainduced mitogenic factor has proangiogenic and proinflammatory effects in the lung via VEGF and VEGF receptor-2. Am J Physiol Lung Cell Mol Physiol 2006, 291:L1159-L1168.

30. Liu T, Dhanasekaran SM, Jin H, Hu B, Tomlins SA, Chinnaiyan AM, Phan SH: FIZZ1 stimulation of myofibroblast differentiation. Am J Pathol 2004, 164:1315-1326.

31. Angelini DJ, Su Q, Yamaji-Kegan K, Fan C, Teng X, Hassoun PM, Yang SC, Champion HC, Tuder RM, Johns RA: Resistin-like molecule-beta in scleroderma-associated pulmonary hypertension. Am J Respir Cell Mol Biol 2009, 41:553-561.

32. Renigunta A, Hild C, Rose F, Klepetko W, Grimminger F, Seeger W, Hanze J: Human RELMbeta is a mitogenic factor in lung cells and induced in hypoxia. FEBS Lett 2006, 580:900-903.

33. Girgis RE, Li D, Zhan X, Garcia JG, Tuder RM, Hassoun PM, Johns RA: Attenuation of chronic hypoxic pulmonary hypertension by simvastatin. Am J Physiol Heart Circ Physiol 2003, 285:H938-H945.

34. Girgis RE, Mozammel S, Champion HC, Li D, Peng X, Shimoda L, Tuder RM, Johns RA, Hassoun PM: Regression of chronic hypoxic pulmonary hypertension by simvastatin. Am J Physiol Lung Cell Mol Physiol 2007, 292:L1105-L1110.

35. Quinlan TR, Li D, Laubach VE, Shesely EG, Zhou N, Johns RA: eNOSdeficient mice show reduced pulmonary vascular proliferation and remodeling to chronic hypoxia. Am J Physiol Lung Cell Mol Physiol 2000 279:L641-L650.

36. Xue C, Johns RA: Upregulation of nitric oxide synthase correlates temporally with onset of pulmonary vascular remodeling in the hypoxic rat. Hypertension 1996, 28:743-753.

37. Cheadle C, Cho-Chung YS, Becker KG, Vawter MP: Application of z-score transformation to Affymetrix data. App/ Bioinformatics 2003, 2:209-217.

38. Nadon R, Woody E, Shi PRN, Hubschle H, Susko E, Ramm P: Statistical inference in array genomics. In Microarrays for the Neurosciences. Edited by Geschwind DH, Gregg J. Cambridge: MIT Press; 2002:109-140.

39. Benjamini $Y$, Hochberg $Y$ : Controlling the false discovery rate: a practical and powerful approach to multiple testing. JRSS-B 1995, 57:289-300.

40. Kim SY, Volsky DJ: PAGE: parametric analysis of gene set enrichment. BMC Bioinformatics 2005, 6:144.

41. Subramanian A, Tamayo P, Mootha VK, Mukherjee S, Ebert BL, Gillette MA, Paulovich A, Pomeroy SL, Golub TR, Lander ES, Mesirov JP: Gene set enrichment analysis: a knowledge-based approach for interpreting genome-wide expression profiles. Proc Natl Acad Sci USA 2005, 102:15545-15550.

42. Cheadle C, Watkins T, Fan J, Williams MA, Georas SN, Hall J, Rosen A, Barnes KC: GSMA Gene Set Matrix Analysis, An automated method for rapid hypothesis testing of gene expression data. Bioinf Biol 2007, 1:49-62.

43. Lammers SR, Kao PH, Qi HJ, Hunter K, Lanning C, Albietz J, Hofmeister S, Mecham R, Stenmark KR, Shandas R: Changes in the structure-function relationship of elastin and its impact on the proximal pulmonary arterial mechanics of hypertensive calves. Am J Physiol Heart Circ Physiol 2008 295:H1451-H1459.

44. Mecham RP, Whitehouse LA, Wrenn DS, Parks WC, Griffin GL, Senior RM, Crouch EC, Stenmark KR, Voelkel NF: Smooth muscle-mediated connective tissue remodeling in pulmonary hypertension. Science 1987, 237:423-426.

45. Stenmark KR, Orton EC, Reeves JT, Voelkel NF, Crouch EC, Parks WC, Mecham RP: Vascular remodeling in neonatal pulmonary hypertension. Role of the smooth muscle cell. Chest 1988, 93:127S-133S

46. Ihida-Stansbury K, McKean DM, Lane KB, Loyd JE, Wheeler LA, Morrell NW, Jones PL: Tenascin-C is induced by mutated BMP type II receptors in familial forms of pulmonary arterial hypertension. Am J Physiol Lung Cell Mol Physiol 2006, 291:L694-L702.
47. Jones PL, Cowan KN, Rabinovitch M: Tenascin-C, proliferation and subendothelial fibronectin in progressive pulmonary vascular disease. Am J Pathol 1997, 150:1349-1360

48. Jones $\mathrm{PL}$, Rabinovitch $\mathrm{M}$ : Tenascin-C is induced with progressive pulmonary vascular disease in rats and is functionally related to increased smooth muscle cell proliferation. Circ Res 1996, 79:1131-1142.

49. Schumann C, Lepper PM, Frank H, Schneiderbauer R, Wibmer T, Kropf C, Stoiber KM, Rudiger S, Kruska L, Krahn T, Kramer F: Circulating biomarkers of tissue remodelling in pulmonary hypertension. Biomarkers 2010, 15:523-532.

50. Baier RJ, Majid A, Parupia H, Loggins J, Kruger TE: CC chemokine concentrations increase in respiratory distress syndrome and correlate with development of bronchopulmonary dysplasia. Pediatr Pulmonol 2004, 37:137-148.

51. Vieillard-Baron A, Frisdal E, Eddahibi S, Deprez I, Baker AH, Newby AC, Berger $P$, Levame M, Raffestin B, Adnot $S$, d'Ortho MP: Inhibition of matrix metalloproteinases by lung TIMP-1 gene transfer or doxycycline aggravates pulmonary hypertension in rats. Circ Res 2000, 87:418-425

52. Nakagami $Y$, Favoreto S Jr, Zhen G, Park SW, Nguyenvu LT, Kuperman DA, Dolganov GM, Huang X, Boushey HA, Avila PC, Erle DJ: The epithelial anion transporter pendrin is induced by allergy and rhinovirus infection, regulates airway surface liquid, and increases airway reactivity and inflammation in an asthma model. J Immunol 2008, 181:2203-2210.

53. Nakao I, Kanaji S, Ohta S, Matsushita H, Arima K, Yuyama N, Yamaya M, Nakayama K, Kubo H, Watanabe M, et al: Identification of pendrin as a common mediator for mucus production in bronchial asthma and chronic obstructive pulmonary disease. J Immunol 2008, 180:6262-6269.

54. Lepetit H, Eddahibi S, Fadel E, Frisdal E, Munaut C, Noel A, Humbert M, Adnot S, D'Ortho MP, Lafuma C: Smooth muscle cell matrix metalloproteinases in idiopathic pulmonary arterial hypertension. Eur Respir J 2005, 25:834-842.

55. Cheadle C, Berger AE, Mathai SC, Grigoryev DN, Watkins TN, Sugawara Y, Barkataki S, Fan J, Boorgula M, Hummers L, et al: Erythroid-specific transcriptional changes in PBMCs from pulmonary hypertension patients. PLoS One 2012, 7:e34951.

56. Buhling F, Rocken C, Brasch F, Hartig R, Yasuda Y, Saftig P, Bromme D, Welte T: Pivotal role of cathepsin K in lung fibrosis. Am J Pathol 2004, 164:2203-2216.

57. van den Brule S, Misson P, Buhling F, Lison D, Huaux F: Overexpression of cathepsin $\mathrm{K}$ during silica-induced lung fibrosis and control by TGF-beta. Respir Res 2005, 6:84.

58. Turnbull IR, Gilfillan S, Cella M, Aoshi T, Miller M, Piccio L, Hernandez M, Colonna M: Cutting edge: TREM-2 attenuates macrophage activation. J Immunol 2006, 177:3520-3524.

59. Rydell-Tormanen K, Uller L, Erjefalt JS: Remodeling of extra-bronchial lung vasculature following allergic airway inflammation. Respir Res 2008, 9:18.

60. Crosby A, Jones FM, Southwood M, Stewart S, Schermuly R, Butrous G, Dunne DW, Morrell NW: Pulmonary vascular remodeling correlates with lung eggs and cytokines in murine schistosomiasis. Am J Respir Crit Care Med 2010, 181:279-288.

61. Crosby A, Jones FM, Kolosionek E, Southwood M, Purvis I, Soon E, Butrous G, Dunne DE, Morrell NW: Praziquantel reverses pulmonary hypertension and vascular remodeling in murine schistosomiasis. Am J Respir Crit Care Med 2011, 184:467-473.

62. Mushaben EM, Hershey GK, Pauciulo MW, Nichols WC, Le Cras TD: Chronic allergic inflammation causes vascular remodeling and pulmonary hypertension in BMPR2 hypomorph and wild-type mice. PLoS One 2012, 7:e32468.

63. Munitz A, Waddell A, Seidu L, Cole ET, Ahrens R, Hogan SP, Rothenberg ME: Resistin-like molecule alpha enhances myeloid cell activation and promotes colitis. J Allergy Clin Immunol 2008, 122:1200-1207. e1201.

64. Kolosova I, Angelini DJ, Fan C, Skinner J, Cheadle C, Johns RA: RELMalpha stimulates proliferation of mesenchymal stem cells while maintaining their multipotency. Stem Cells Dev 2012, In Press.

65. Tong $Q$, Zheng L, Lin L, Li B, Wang D, Huang C, Li D: VEGF is upregulated by hypoxia-induced mitogenic factor via the PI-3K/Akt-NF-kappaB signaling pathway. Respir Res 2006, 7:37

66. Tong Q, Zheng L, Lin L, Li B, Wang D, Huang C, Matuschak GM, Li D: Participation of the PI-3K/Akt-NF-kappa B signaling pathways in hypoxiainduced mitogenic factor-stimulated Flk-1 expression in endothelial cells. Respir Res 2006, 7:101

67. Tong $Q$, Zheng L, Lin L, Li B, Wang D, Li D: Hypoxia-induced mitogenic factor promotes vascular adhesion molecule-1 expression via the PI-3K/Akt-NFkappaB signaling pathway. Am J Respir Cell Mol Biol 2006, 35:444-456. 
68. Wagner KF, Hellberg AK, Balenger S, Depping R, Dodd OJ, Johns RA, Li D: Hypoxia-induced mitogenic factor has antiapoptotic action and is upregulated in the developing lung: coexpression with hypoxiainducible factor-2alpha. Am J Respir Cell Mol Biol 2004, 31:276-282.

69. Li D, Fernandez LG, Dodd-o J, Langer J, Wang D, Laubach VE: Upregulation of hypoxia-induced mitogenic factor in compensatory lung growth after pneumonectomy. Am J Respir Cell Mol Biol 2005, 32:185-191.

70. Chung MJ, Liu T, Ullenbruch M, Phan SH: Antiapoptotic effect of found in inflammatory zone (FIZZ)1 on mouse lung fibroblasts. J Pathol 2007, 212:180-187.

71. Tong Q, Zheng L, Dodd-o J, Langer J, Wang D, Li D: Hypoxia-induced mitogenic factor modulates surfactant protein $B$ and $C$ expression in mouse lung. Am J Respir Cell Mol Biol 2006, 34:28-38,

72. Tong Q, Zheng L, Li B, Wang D, Huang C, Matuschak GM, Li D: Hypoxiainduced mitogenic factor enhances angiogenesis by promoting proliferation and migration of endothelial cells. Exp Cell Res 2006, 312:3559-3569.

doi:10.1186/1465-9921-14-1

Cite this article as: Angelini et al: Hypoxia-induced mitogenic factor (HIMF/FIZZ1/RELMa) in chronic hypoxia- and antigen-mediated pulmonary vascular remodeling. Respiratory Research 2013 14:1.

\section{Submit your next manuscript to BioMed Central and take full advantage of:}

- Convenient online submission

- Thorough peer review

- No space constraints or color figure charges

- Immediate publication on acceptance

- Inclusion in PubMed, CAS, Scopus and Google Scholar

- Research which is freely available for redistribution
( Biomed Central 